http://jmscr.igmpublication.org/home/ ISSN (e)-2347-176x ISSN (p) 2455-0450

crossref DOI: https://dx.doi.org/10.18535/jmscr/v8i4.08

\title{
Prevalence of subclinical hypothyroidism in diagnosed cases of gall stone disease: Prospective study from a tertiary care institute in Himalayan region
}

\author{
Authors
Dr Mahender Singh Rana ${ }^{1 *}$, Dr Mohit Bajaj ${ }^{2}$, Dr Aman Thakur ${ }^{3}$, Dr Ashok Kaundal ${ }^{4}$, Dr Anil Malhotra ${ }^{5}$, Dr Ashish Sharma ${ }^{6}$, Dr Abhinav Chaudhary ${ }^{7}$
*Corresponding Author \\ Dr Mahender Singh Rana \\ Senior Resident, Department of Surgery, DR RPGMC TANDA
}

\begin{abstract}
Gall stones are the most common biliary pathology, recent studies show that 10-15\% of adult population in USA has gall stones (20 millions), 3\% of them underwent cholecystectomy, 85\% of them asymptomatic, $1-4 \%$ of them develop symptoms each year, females more affected than males $3: 1^{1,2}$. For decades there has been a discussion, whether thyroid disorders could cause gallstone disease. Interestingly it has been reported that the risk, in particular, for gall stones, increases in clinical and subclinical hypothyroidism. There are multiple factors that may contribute to the formation and/or accumulation of gall stones in hypothyroid patients, including decreased liver cholesterol metabolism, diminished bile secretion, and reduced Sphincter of Oddi relaxation.

Objective: To assess the prevalence of hypothyroidism in patients with gall stones and try to establish hypothyroidism as a possible etiological factor for gallstones formation.

Methods: A cross sectional study was carried out at IGMC \& Hospital involving 149 patients with cholelithiasis admitted to the hospital during the period from April 2016 to October 2017. All patients were assessed by detailed clinical history and examination with appropriate investigations in form of abdominal USG, thyroid function tests and lipid profile.

Results: Out of 149 patients of gallstone, 120 patients were euthyroid and 29 patients were having subclinical hypothyroidism. Maximum number of patients belonged to the age group of 41-50 years (31.54\%).Majority were female, i.e. 107 (72\%). Out of the 29 patients diagnosed with subclinical hypothyroidism, $21(72 \%)$ were female $.77(51.67 \%)$ patients presented with complaints of fatty dyspepsia followed by 57(38.25)\% with biliary colic and 15(10.66\%) with pain right hypochondrium.

Keywords: Hypothyroidism, Gall stones, Subclinical Thyroid dysfunction.
\end{abstract}

\section{Introduction}

The prevalence of gall stone disease is around 2$29 \%$ in the Indian subcontinent. Its prevalence varies along demography, age, sex, geography, food habits, sedentary life style and obesity. Until now, Cholelithiasis was believed to occur in sedentary people and was thought to be associated with lipid disorder. It was considered to be a disease of fat, forty and fertile females. Now the focus has shifted to its association with hypothyroidism since many patients with cholelithiasis were found to have hypothyroidism 
in the last two decades. Hypothyroidism, not only increases the risk for gallbladder stones ${ }^{3,4}$, but also the risk for common bile duct (CBD) stones, in particular. $^{5-7}$

Overt and subclinical hypothyroidism is also quite common in the Indian population, the prevalence being $5-15 \%$ and $8-12 \%$ respectively. These conditions are quite often under diagnosed, especially in mountain and hilly regions due to the absence of symptoms and are revealed onlyon thyroid assays, chiefly TSH.

\section{Materials and Methods}

\section{Type of Study and Sample Size}

Prospective time bound non randomized study done on all the patients of gall stone disease admitted in Department of Surgery, IGMC Shimla from June 2016 to may 2017.

\section{Inclusion Criteria}

Patients with ultrasound proven cholelithiasis.

\section{Exclusion Criteria}

Patients with a history of previously diagnosed or treated thyroid function abnormalities, history of thyroidectomy, ongoing pregnancy, serious underlying diseases, patients on oral contraceptives, sepsis or cholangitis and those prescribed medications known to affect the thyroid function test such as phenytoin, carbamazepine, metoclopramide, amiodarone, and lithium.

\section{Study Design}

The study population was divided according to the TSH and T3/T4 reference values that were provided by the laboratory into three groups:

1. Subclinical hypothyroidism: symptom free patients with TSH concentration above upper limit of normal range and normal values of $\mathrm{T} 3 / \mathrm{T} 4$.

2. Clinical hypothyroidism: in which there are symptoms of hypothyroidism with TSH level above the upper limit and T3/T4 below normal limit.

3. Euthyroid group: in which clinical and lab tests are within normal range.
3-4 $\mathrm{ml}$ of venous blood was collected and sent to the central laboratory of hospital for the estimation of serum T3 T4 and TSH. The functional sensitivity of the TSH assay was 0.03 $\mathrm{mIU} / \mathrm{L}$. The reference range was 0.3-3 mIU/L.

The normal reference range for $\mathrm{T} 3, \mathrm{~T} 4$ and $\mathrm{TSH}$ in laboratory is $80-210 \mathrm{ng} / \mathrm{ml}, 4.8-12 \mu \mathrm{g} / \mathrm{dl}$ and $0.35-4.94 \mu \mathrm{IU} / \mathrm{ml}$. The minimum detectable concentration of $\mathrm{T} 3$ and $\mathrm{T} 4$ by this assay is estimated to be $0.2 \mathrm{ng} / \mathrm{ml}$ and $.4 \mu \mathrm{g} / \mathrm{dl}$ respectively.

A complete clinical profile i.e. a detailed history was recorded and physical examination done. Routine blood examination, liver function test, thyroid function test and ultrasound abdomen was performed in every case at the time of admission. USG abdomen was done using a $5 \mathrm{MHz}$ transducer and a high resolution monitor. The sonographers were unaware of the participant's clinical and laboratory characteristics. Gallstones were present if the gallbladder contained echoes that moved with gravity except when the stones were large, a septum existed in the gallbladder or there was an enclosed infundibulum. ${ }^{12}$ Cholelithiasis was defined as sonographically diagnosed gallstones.

\section{Statistical Analysis}

Data on quantitative characteristics were expressed as mean $\pm \mathrm{SD}$. Data on qualitative characteristics were expressed as percentage values or absolute numbers as indicated. Comparisons between groups were made using $\chi 2$-test (nominal data) and analysis of variance (ANOVA, continuous data). Sex-stratified logistic regression was performed in order to evaluate independent relationships between thyroid function and cholelithiasis. All analyses were adjusted for age and further potential confounders. All statistical analyses were performed with SPSS software, version 11.0.5 (SPSS GmbH Software, Munich, Germany. 


\section{Observations and Results}

Table 1 Age-group based distribution of Patients $(n=149)$

\begin{tabular}{|l|c|c|}
\hline Age Group & Frequency & Percentage \\
\hline$<10$ Years & 1 & $0.67 \%$ \\
\hline 11-20 Years & 1 & $0.67 \%$ \\
\hline 21-30 Years & 10 & $6.71 \%$ \\
\hline 31-40 Years & 35 & $23.48 \%$ \\
\hline 41-50 Years & 47 & $31.54 \%$ \\
\hline 51-60 Years & 27 & $18 . .12 \%$ \\
\hline 61-70 Years & 24 & $16.10 \%$ \\
\hline 71-80 Years & 4 & $2.68 \%$ \\
\hline Total & 149 & $100 \%$ \\
\hline
\end{tabular}

Table 2 Gender wise distribution of Patients $(n=149)$

\begin{tabular}{|l|c|c|}
\hline Sex & Frequency & Percentage \\
\hline Female & 107 & $72 \%$ \\
\hline Male & 42 & $28 \%$ \\
\hline Total & 149 & $100 \%$ \\
\hline
\end{tabular}

Table 3 Thyroid function status of enrolled patients

\begin{tabular}{|l|c|c|}
\hline TFT & Frequency & Percentage \\
\hline Euthyroid & 120 & $80.5 \%$ \\
\hline $\begin{array}{l}\text { Subclinical } \\
\text { Hypothyroid }\end{array}$ & 29 & $19.5 \%$ \\
\hline Total & 149 & $100 \%$ \\
\hline
\end{tabular}

Table 4 Gender-wise distribution of patients with Subclinical hypothyroidism $(n=29)$

\begin{tabular}{|l|c|}
\hline Sex & $\begin{array}{c}\text { Subclinical hypothyroidism } \\
(\mathbf{n = 2 9})\end{array}$ \\
\hline Female & $21(72 \%)$ \\
\hline Male & $8(28 \%)$ \\
\hline Total & $29(100 \%)$ \\
\hline
\end{tabular}

Table 5 Symptoms-based distribution of patients $(\mathrm{n}=149)$

\begin{tabular}{|l|c|c|}
\hline $\begin{array}{l}\text { Symptoms of } \\
\text { Cholelithiasis }\end{array}$ & Frequency & Percentage \\
\hline Biliary colic & 57 & $38.25 \%$ \\
\hline Fatty dyspepsia & 77 & $51.67 \%$ \\
\hline Pain Right Hypochondrium & 15 & $10.66 \%$ \\
\hline Total & 149 & $100 \%$ \\
\hline
\end{tabular}

Table 6 Symptoms-based Gender Wise distribution of patients $(n=149)$

\begin{tabular}{|l|c|c|c|}
\hline Sex & $\begin{array}{c}\text { History of } \\
\text { Biliary colic }\end{array}$ & $\begin{array}{c}\text { Fatty } \\
\text { dyspepsia }\end{array}$ & $\begin{array}{c}\text { Pain Right } \\
\text { Hypochondrium }\end{array}$ \\
\hline Female & 44 & 50 & 13 \\
\hline Male & 13 & 27 & 2 \\
\hline Total & 57 & 77 & 15 \\
\hline
\end{tabular}

\section{Discussion}

The relatively small number of patients resulted from the exclusion of patients with Previously known thyroid disorder who were 102 patients. The patients were excluded due to previous thyroid surgery, receiving thyroid medication, with choledocholithiasis and ingestion of radioactive iodine administration.

Subclinical hypothyroidism is a predominant disorder among adult population; however, it is often overlooked.

\section{Age Distribution}

In our study, youngest patient was of 8 years of age and eldest was 74 years old. Majority of patients were in the age group of 41-50 years $(31.54 \%)$ and this can be contributed to the sex hormone imbalance of this age group which is similar to the study done by Ahmed et $\mathbf{a l}^{\mathbf{8}}$ where eight patients of total 100 patients who were detected as having subclinical hypothyroidism were in the age group of 41-70 years. Among 8 patients detected as hypothyroid in the study group, 5 were in the age group of 51-60 years illuminating an increasing occurrence of sub clinical hypothyroidism with age.

Age is a main risk factor for gallstones formation, the age of 40 years appears to denote the cut-off between relatively low and high rates of cholecystectomies. Between the ages of 40 and 69 years, the incidence is 4 times higher than in younger subjects. Laukkarinen et al. ${ }^{\mathbf{9}}$ study show that thyroid function abnormalities even mild and preclinical should be screened in patients with gallstones' especially in women above 60 years. This matched with our result study about age group and its distribution because with increasing age there is decrease in water contents of body which may reach $45 \%$ of body weight, this is due to decrease in lean (muscle) mass of the body which may lead to more concentrated body fluids and excretions and more deposition of solid contents of the excretions which may lead to nucleation and formation of gall stone. 


\section{Sex Distribution}

Of the 149 patients, majority were female, i.e. 107 (72\%). The three F's associated with gall stones i.e. Forty, Fatty and Fertile female is well known worldwide. This study also supports the above said saying by giving a recording of $72 \%$ of gall stones in women compared to $28 \%$ in men which is in concordance with a study conducted by Volzke $\mathbf{H}$ et $\mathbf{a l}^{\mathbf{1 0}}$ showing that women were affected nearly twice as often as men, while gallstones were only slightly more often detected by ultrasound in women than in men.

\section{Thyroid Function Status}

Out of 149 patients subjects, $120(80.5 \%)$ were found to be euthyroid whereas $29(19.5 \%)$ were found to be in the range of subclinical hypothyroidism.

In a study done by Johanna et $\mathbf{a l}^{\mathbf{1 1}}$ in 2007, the prevalence of subclinical hypothyroidism was $11.4 \%$, which is close to that of our study $(19.5 \%)$.

Out of the 29 patients diagnosed with subclinical hypothyroidism, 21(72\%) were female and $8(28 \%)$ were male which is in concordance with study done by Volzke $\mathrm{H}$ et al. $^{10}$ on earlier diagnosis and treatment of hypothyroidism in women compared to men. This assumption is supported by the fact that the association between high serum TSH levels and cholelithiasis was mainly found in females with sonographically detected gallstones as proved in our study and still more predominant in female gender.

\section{Conclusion}

From our study, it is evident that subclinical hypothyroidism is also associated with gall stones and that too in women, in the age group of more than 40.Most importantly, when treating patients with gall stones or microlithiasis, clinicians should be aware of the possible hypothyroid background and consider examining the thyroid function, at least in female patients over 40 years of age, in which group the prevalence of clinical and subclinical hypothyroidism is the highest. Since it is associated with increased serum TSH alone, this can be used as a serum marker and further complications of gall stones can be avoided.

Ethical Approval: Yes Ethical Approval and patient consent were taken under supervision of ethical committee of surgery, Department of Surgery, IGMC SHIMLA.

Sources of Funding: There is no funding for my research.

Conflicts of Interest: There is no conflict of interest.

\section{Bibliography}

1. I .J. Beckingham, B.J. Rowlands Post cholecystectomy problems. H. Blumgart (ED.), Surgery of Liver and Biliary Tract $3^{\text {rd }}$ edition, WB Saunders, London (2000),p 186

2. A. Nakeeb, A.G. Comuzzie, L. Martin, et al. Gall stones: genetics versus environment Ann. Surg., 235(2002),p.842.

3. Canaris GJ, Manowitz NR, Mayor G, Ridgway EC. The Colorado thyroid disease prevalence study. Arch Intern Med. 2000;160:526-534.

4. Laukkarinen J, Sand J, Saaristo R, Salmi J, Turjanmaa V, Vehkalahti P, Nordback I. Is bile flow reduced in patients with hypothyroidism? Surgery. 2003;133:288293.

5. Inkinen J, Sand J, Arvola P, Pörsti I, Nordback I. Direct effect of thyroxine on pig sphincter of Oddi contractility. Dig Dis Sci. 2001;46:182-186.

6. Cicala M, Habib FI, Fiocca F, Pallotta N, Corazziari E. Increased sphincter of Oddi basal pressure in patients affected by gall stone disease: a role for biliary stasis and colicky pain? Gut. 2001;48:414-417.

7. Honoré LH. A significant association between symptomatic cholesterol cholelithiasis and treated hypothyroidism in women. J Med. 1981;12:199-203.

8. Mir Mujtaba Ahmad, Mir Irfan Nazirl, Haneef Mohamed Darl, et al. Evaluation 
of thyroid profile in biliary tract stones International Surgery Journal, 12 (3) (2015), p. 344

9. J. Laukkarinen, J. Sand, R. Saaristo et al., "Is bile flow reduced in patients with hypothyroidism?" Surgery, vol. 133, no. 3, pp. 288-293, 2003.

10. Volzke Henry, Daniel M. Robinson, John Ulrich, et al. Association between thyroid function and gallstone disease World J. Gastroenterol., 2 (35) (2005)

11. J. Laukkarinen, G. Kiudelis, M. Lempinen, et al. Increased prevalence of subclinical hypothyroidism Metab, 92 (11) (2007), pp. 4260-4264.

12. Völzke H, Lüdemann J, Robinson DM, Spieker KW, Schwahn C, Kramer A, John $\mathrm{U}$, Meng $\mathrm{W}$. The prevalence of undiagnosed thyroid disorders in a previously iodine-deficient area. Thyroid. 2003;13:803-810. 